\title{
Dietary low-glucosinolate rapeseed meal affects thyroid status and nutrient utilization in rainbow trout (Oncorhynchus mykiss)
}

\author{
Christine Burel $^{1}$, Thierry Boujard ${ }^{1}$, Anne-Marie Escaffre ${ }^{1}$, Sadasivam J. Kaushik ${ }^{1}$, \\ Gilles Boeuf ${ }^{2}$, Koen A. $\mathrm{Mol}^{3}$, Serge Van der Geyten ${ }^{3}$ and Eduard R. Kühn ${ }^{3}$ \\ ${ }^{1}$ Laboratoire de Nutrition des Poissons, Unité mixte INRA-IFREMER, Station d'Hydrobiologie, BP 3, \\ 64310 Saint Pée-sur-Nivelle, France \\ ${ }^{2}$ Laboratoire de Physiologie des Poissons, IFREMER, Station de Brest, BP 70, 29280, Plouzané, France \\ ${ }^{3}$ Laboratory of Comparative Endocrinology, Catholic University of Leuven, Naamsestraat 59, 3000 Leuven, Belgium
}

(Received 29 July 1999 - Revised 29 October 1999 - Accepted 12 November 1999)

\begin{abstract}
Two rapeseed (Brassica napus) meals, RM1 and RM2, with two levels of glucosinolates (GLS; 5 and $41 \mu \mathrm{mol} / \mathrm{g}$ DM respectively) were incorporated at the levels of 300 and $500 \mathrm{~g} / \mathrm{kg}$ of the diets of juvenile rainbow trout (Oncorhynchus mykiss) in replacement of fish meal, and compared with a fish-meal-based diet. A decrease in the digestibility of the DM, protein, gross energy and $\mathrm{P}$ was observed with high-rapeseed meal (RM) incorporation. In trout fed on RM-based diets, growth performance was reduced even after only 3 weeks of feeding. Feed efficiency was adversely affected by RM and GLS intake. Protein and energy retention coefficients were significantly lower in fish fed on the diet containing the higher level of GLS. P retention was significantly lower with all the RM-based diets than with the fish-meal diet. Irrespective of the degree of growth inhibition, fish fed on RM-based diets exhibited similar typical features of hypothyroid condition due to GLS intake, expressed by lower plasma levels of triiodothyronine and especially thyroxine and a hyperactivity of the thyroid follicles. This hypothyroidal condition led to a strong adjustment of the deiodinase activities in the liver, the kidney and the brain. A significant increase of the outer ring deiodinase activities (deiodinases type I and II respectively) and a decrease of the inner ring deiodinase activity (deiodinase type III) were observed. It is concluded that the observed growth depression could be attributed to the concomitant presence of GLS, depressing the thyroid function, and of other antinutritional factors affecting digestibility and the metabolic utilization of dietary nutrients and energy.
\end{abstract}

Rainbow trout: Rapeseed: Growth: Glucosinolates: Thyroid function

Rapeseed is primarily grown for its high oil content $(400-450 \mathrm{~g} / \mathrm{kg}$ seed) but the defatted meal is also used as a source of protein for mammals and poultry. Rapeseeds are nevertheless known to contain antinutritional factors, such as a high fibre content, tannins, phytic acid and glucosinolates (anionic $\beta$-thio-D-glucopyrranosides encountered in the leaves, seeds, flowers and roots of a large variety of plants, such as rapes). The incorporation of rapeseed meals (RM) containing high levels of glucosinolates (GLS) to animal feed leads to reduced feed intake, enlarged thyroid, reduced plasma thyroid hormone levels and, occasionally, organ abnormalities (liver and kidney) and even mortality (Bunting, 1981; VanEtten \& Tookey, 1983).

On account of its good amino acid profile, many studies since the seventies have focused on the incorporation of RM into fish feed (Yurkowski et al. 1978; Teskeredzic et al.
1995; Webster et al. 1997). A comprehensive review has also been made by Higgs et al. (1996). In brief, it has been shown that the deleterious effects of the high levels of fibre and of the GLS restrict the level of incorporation of RM into fish feeds to approximately $200 \mathrm{~g} / \mathrm{kg}$ (Yurkowski et al. 1978; Hardy \& Sullivan, 1983; Hilton \& Slinger, 1986; Leatherland et al. 1987; Gomes \& Kaushik, 1989; Gomes et al. 1993; Higgs et al. 1996). However, significant improvements have been made to reduce the levels of GLS below $20 \mu \mathrm{mol} / \mathrm{g}$ and to improve the nutritional value of RM by genetic selection of cultivars (Vermorel et al. 1986) and by the use of new processing techniques (Bell, 1993).

Studies carried out by Vermorel \& Baudet (1987) in terrestrial animals and by Hardy \& Sullivan (1983) in trout have shown that thyroidal disturbances (decreasing plasma triiodothyronine $\left(\mathrm{T}_{3}\right)$ and thyroxine $\left(\mathrm{T}_{4}\right)$ levels) caused by

\footnotetext{
Abbreviations: ADC, apparent digestibility coefficient; D, deiodinase; IRD, inner ring deiodination; GLS, glucosinolates; ORD, outer ring deiodination; $\mathrm{RM}$, rapeseed meal; $\mathrm{rT}_{3}, 3,3^{\prime}, 5^{\prime}$-triiodothyronine; $\mathrm{T}_{3}$, triiodothyronine; $\mathrm{T}_{4}$, thyroxine.

* Corresponding author: Dr Thierry Boujard, fax +33(0) 5595451 52, email boujard@st-pee.inra.fr
} 
RM ingestion occurred at a level of incorporation lower than the level which led to growth depression. Higgs et al. (1982) and Hardy \& Sullivan (1983) suspected the existence of a compensatory effect, likely to happen through an adjustment of the deiodinase activities. In all vertebrates, $\mathrm{T}_{4}$ is the main secretory product of the thyroid follicles even though $\mathrm{T}_{3}$ is the biologically active hormone. Outer ring deiodination (ORD) converts $T_{4}$ into $T_{3}$ and reverse $T_{3}\left(3,3^{\prime}, 5^{\prime}\right.$ triiodothyronine $\left(\mathrm{rT}_{3}\right)$ into 3,5-diiodothyronine $\left(\mathrm{T}_{2}\right)$. Inner ring deiodination (IRD) converts $\mathrm{T}_{4}$ into $\mathrm{rT}_{3}$ and degrades active $T_{3}$ to $T_{2}$. The ORD reaction is the activating pathway of $\mathrm{T}_{4}$ metabolism as it produces $\mathrm{T}_{3}$, while the IRD reaction is considered to be the inactivating pathway as it degrades $\mathrm{T}_{4}$ and inactivates $\mathrm{T}_{3}$ (Kühn et al. 1993). Three types of deiodinases have been characterized in mammals (Leonard \& Visser, 1986). Type I deiodinase (D1) can catalyse both ORD and IRD and has a substrate preference for $\mathrm{rT}_{3}$, but can also convert $\mathrm{T}_{4}$ into $\mathrm{T}_{3}$. Type II deiodinase (D2) performs only ORD, and prefers $\mathrm{T}_{4}$ as the substrate. Type III deiodinase (D3) has exclusive IRD activity and deiodinates $\mathrm{T}_{3}$ preferentially. Recent studies have demonstrated that deiodinating activities similar to the mammalian D1, D2 and D3 are also found in five teleosts, including rainbow trout (Oncorhynchus mykiss) (Mol et al. 1998). Generally, in studies with fish, only the hepatic $\mathrm{T}_{4}$ ORD (D2) reaction in liver has been considered, which may neglect an important part of the peripheral thyroid metabolism.

In this present study, two RM with different levels of GLS (5 to $41 \mathrm{~mol} / \mathrm{kg} \mathrm{DM}$ ) were incorporated each at two levels ( 300 and $500 \mathrm{~g} / \mathrm{kg}$ ) in the diets of rainbow trout. The aim of the study was to determine a possible relationship between thyroidal-axis status (plasma levels of thyroid hormones, deiodinase activities, i.e. D1, D2 and D3 in different tissues and the activity of thyroid follicles) and growth and nutrient and energy utilization in rainbow trout.

\section{Materials and methods}

Two different rapeseed meals (Brassica napus) (provided by the Centre Technique Interprofessionnel des Oléagineux Métropolitains (CETIOM), Paris, France) with different levels of GLS were used. Rapeseeds were first subjected to an intense dehulling treatment in order to reduce their fibre content. Two different oil-extraction processes were then used. The first consisted of a pressure-cooking $\left(97^{\circ}\right.$, $5000 \mathrm{kPa}$ ) under wet conditions. Any remaining oil was extracted by six consecutive hexane washings in percolation, followed by removal of solvent by steam injection $\left(105^{\circ}, 600 \mathrm{kPa}\right)$. Subsequent grinding produced rapeseed meal 1 (RM1). The method used to obtain rapeseed meal 2 (RM2) consisted of a direct oil extraction. Rapeseeds were subjected to a double pressing, and oil was removed by eight consecutive hexane washings. The removal of solvent was done using steam injection $\left(80^{\circ}, 300 \mathrm{kPa}\right)$. The thermal treatment applied to RM1 significantly decreased the total GLS level to $5 \mathrm{~mol} / \mathrm{kg} \mathrm{DM}$, compared with RM2 which contained $41 \mathrm{~mol} / \mathrm{kg} \mathrm{DM}$ (analyses were carried out by the Laboratoire d'Analyse du Cetiom, Orléans, France). Six different GLS were identified in RM1. Of these, progoitrine $(2.2 \mathrm{~mol} / \mathrm{kg} \mathrm{DM})$ and gluconapine $(1.2 \mathrm{~mol} / \mathrm{kg} \mathrm{DM})$ were the most important. Ten different GLS were identified in RM2. Progoitrine (17.2 mol/kg DM), gluconapine (6.9 mol/kg DM), glucobrassicanapine $(2 \cdot 2 \mathrm{~mol} / \mathrm{kg} \mathrm{DM})$, sinalbine $(4.5 \mathrm{~mol} / \mathrm{kg}$ $\mathrm{DM})$ and glucobrassicine $(7.6 \mathrm{~mol} / \mathrm{kg} \mathrm{DM})$ were the major components. A conversion factor of 0.432 , based on the molar weight of each GLS and their average proportion in RM, can be applied to convert the GLS values expressed as $\mathrm{mol} / \mathrm{kg}$ to $\mathrm{g} / \mathrm{kg}$. The chemical composition of these two RM is shown in Table 1. Their amino acid profiles meet the requirements of rainbow trout (Tables 2 and 3 ).

\section{Diets and digestibility measurements}

For the growth study, five experimental diets were formulated (Table 3), containing respectively no rapeseed (control diet), 300 and $500 \mathrm{~g} \mathrm{RM} 1 / \mathrm{kg}$ (R1-300 and R1-500 diets), 300 and $500 \mathrm{~g} \mathrm{RM} 2 / \mathrm{kg}$ (R2-300 and R2-500 diets).

The apparent digestibility coefficients (ADC) of the diets were measured using the indirect method developed by Choubert (1999) with diets containing $\mathrm{Cr}_{2} \mathrm{O}_{3}(10 \mathrm{~g} / \mathrm{kg})$ as an inert tracer. Ten tanks (60 litres capacity with a flow rate of 5 litres $/ \mathrm{min}, 16 \cdot 5^{\circ}$ ) with twenty fish in each (body weight about $100 \mathrm{~g}$ each) were adapted to the experimental conditions (12 h light-12 h dark) and fed on one of the experimental diets for $7 \mathrm{~d}$ before the start of faecal collection. Faecal samples were collected continuously during $7 \mathrm{~d}$ from each tank using the apparatus developed by Choubert et al. (1982). After freeze-drying, the faeces (two samples per

Table 1. Chemical composition of the fish meal* and rapeseed meals $\dagger$

\begin{tabular}{lccc}
\hline & Fish meal & Rapeseed meal 1 & Rapeseed meal 2 \\
\hline Dry matter (g/kg DM) & 902 & 906 & 948 \\
Ash (g/kg DM) & 173 & 78 & 76 \\
Crude protein (g/kg DM) & 693 & 453 & 446 \\
Crude fat (g/kg DM) & 98 & 18 & 13 \\
Phosphorus (g/kg DM) & 21 & 16 & 16 \\
Starch (g/kg DM) & - & 52 & 45 \\
N-free extracts (g/kg DM)‡ & - & 399 & 420 \\
Energy (kJ/kg DM) & 2060 & 1970 & 1940 \\
Phytic acid (g/kg DM) & - & $4 \cdot 2$ & 4.4 \\
Glucosinolates (mol/kg DM) & - & $5 \cdot 1$ & $40 \cdot 7$ \\
\hline
\end{tabular}

DM, dry matter.

${ }^{\star}$ Norwegian herring meal.

tFor details of the oil-extraction processes used to prepare rapeseed meals 1 and 2 , see above.

$\ddagger$ The amount of $\mathrm{N}$-free extracts (lignin, non-starch polysaccharides, oligosaccharides) was estimated as follows: $N$-free extracts $(\mathrm{g} / \mathrm{kg}$ dry matter $)=100-($ ash + crude protein + crude fat + starch $)$. 
Table 2. Essential amino acid composition ( $\mathrm{g} / 16 \mathrm{~g}$ nitrogen) of the fish meal ${ }^{\star}$ and rapeseed meal $\dagger$ as compared with the requirements of trout

\begin{tabular}{|c|c|c|c|c|}
\hline Amino acid & Trout requirements $\ddagger$ & Fish meal & Rapeseed meal 1 & Rapeseed meal 2 \\
\hline$\overline{A r g}$ & 3.6 & 5.0 & 6.8 & 7.9 \\
\hline Lys & $5 \cdot 3$ & $5 \cdot 8$ & $6 \cdot 6$ & $6 \cdot 6$ \\
\hline His & 1.6 & 2.5 & $2 \cdot 6$ & $3 \cdot 3$ \\
\hline lle & 2.4 & 4.3 & 3.8 & 4.3 \\
\hline Leu & 4.4 & 7.3 & 4.5 & $6 \cdot 1$ \\
\hline Val & 3.2 & 5.4 & 3.7 & 4.3 \\
\hline Met & 1.8 & 2.4 & 1.9 & 2.3 \\
\hline Cys & 0.9 & 0.9 & 2.5 & 2.5 \\
\hline Phe & 3.2 & 4.0 & 4 & 3.8 \\
\hline Tyr & 2.0 & 3.2 & 4 & 4.2 \\
\hline Thr & 3.3 & 3.6 & 4.9 & 5.6 \\
\hline Trp & 0.6 & $1 \cdot 1$ & 1.3 & 1.3 \\
\hline
\end{tabular}

*Norwegian herring meal.

†For details of the oil-extraction processes used to prepare rapeseed meals 1 and 2, see p. 654 .

$\ddagger$ Requirements according to the National Research Council (1993).

Table 3. Ingredients and chemical composition of diets used in the growth experiment

\begin{tabular}{|c|c|c|c|c|c|c|}
\hline & \multicolumn{5}{|c|}{ Diets } & \multirow{2}{*}{$\begin{array}{c}\text { Trout } \\
\text { requirements }\end{array}$} \\
\hline & Control & $\mathrm{R} 1-300$ & $R 1-500$ & $\mathrm{R} 2-300$ & $\mathrm{R} 2-500$ & \\
\hline \multicolumn{7}{|l|}{ Ingredients (g/kg) } \\
\hline Rapeseed meal $1^{*}$ & _- & 30 & 50 & _- & - & \\
\hline Rapeseed meal $2^{*}$ & - & - & - & 30 & 50 & \\
\hline Fish mealt & 53 & 35 & $20 \cdot 5$ & 35 & 21 & \\
\hline Soluble fish protein concentrate & 3 & 3 & 3 & 3 & 3 & \\
\hline Flaked maize & 32 & 18 & $10 \cdot 5$ & 18 & 9 & \\
\hline Fish oil & 9 & 11 & 13 & 11 & 14 & \\
\hline Vitamin mixture $\ddagger$ & 1 & 1 & 1 & 1 & 1 & \\
\hline Mineral mixture§ & 1 & 1 & 1 & 1 & 1 & \\
\hline Binder (sodium alginate) & 1 & 1 & 1 & 1 & 1 & \\
\hline \multicolumn{7}{|l|}{ Chemical composition } \\
\hline Dry matter $(\mathrm{g} / \mathrm{kg})$ & 940 & 942 & 942 & 933 & 941 & \\
\hline Ash (g/kg DM) & 104 & 92 & 82 & 92 & 83 & \\
\hline Phosphorus (g/kg DM) & 15 & 15 & 14 & 15 & 14 & \\
\hline Crude protein (g/kg DM) & 400 & 402 & 387 & 402 & 389 & \\
\hline \multicolumn{7}{|l|}{ Amino acids (g/kg DM) } \\
\hline Arg & 19 & 22 & 23 & 23 & 25 & 14 \\
\hline Lys & 22 & 24 & 24 & 24 & 24 & 21 \\
\hline His & 10 & 10 & 10 & 11 & 11 & 6 \\
\hline Ile & 17 & 17 & 15 & 17 & 17 & 10 \\
\hline Leu & 31 & 27 & 23 & 29 & 26 & 18 \\
\hline Val & 21 & 19 & 17 & 20 & 19 & 13 \\
\hline Met & 9 & 9 & 8 & 9 & 9 & 7 \\
\hline Cys & 4 & 6 & 7 & 6 & 7 & 4 \\
\hline Phe & 16 & 16 & 15 & 16 & 15 & 13 \\
\hline Tyr & 12 & 14 & 14 & 14 & 15 & 8 \\
\hline Thr & 14 & 16 & 17 & 17 & 18 & 13 \\
\hline Trp & 4 & 5 & 5 & 5 & 5 & 2 \\
\hline Crude fat ( $\mathrm{g} / \mathrm{kg} \mathrm{DM})$ & 161 & 169 & 171 & 159 & 158 & \\
\hline Starch (g/kg DM) & 228 & 123 & 722 & 125 & 562 & \\
\hline $\mathrm{N}$-free extracts $(\mathrm{g} / \mathrm{kg} \mathrm{DM}) \|$ & 107 & 214 & 288 & 222 & 314 & \\
\hline Gross energy (kJ/kg DM) & 2140 & 2190 & 2200 & 2190 & 2230 & \\
\hline Digestible protein ( $/ \mathrm{kg} \mathrm{DM}) \emptyset$ & 356 & 363 & 349 & 362 & 336 & \\
\hline Digestible energy (g/kg DM) & 180 & 182 & 179 & 178 & 174 & \\
\hline Digestible protein : digestible energy value $(\mathrm{mg} / \mathrm{kJ})$ & $19 \cdot 7$ & 19.9 & 17.9 & $17 \cdot 8$ & $17 \cdot 4$ & \\
\hline Glucosinolates $(\mathrm{mol} / \mathrm{kg} \mathrm{DM})^{\star *}$ & - & 1.4 & $2 \cdot 3$ & 11.6 & $19 \cdot 3$ & \\
\hline
\end{tabular}

DM, dry matter.

${ }^{*}$ For details of the oil-extraction processes used to prepare rapeseed meals 1 and 2, see p. 654.

† Norwegian herring meal, $700 \mathrm{~g}$ crude protein $/ \mathrm{kg}$.

$\ddagger$ National Research Council (1993).

$\S$ Mineral mixture contained (/kg diet): calcium carbonate $1.12 \mathrm{~g}$, magnesium oxide $0.62 \mathrm{~g}$, ferric citrate $0.1 \mathrm{~g}$, potassium iodide $0.2 \mathrm{mg}$, zinc sulfate $0.2 \mathrm{~g}$, copper sulfate $0.15 \mathrm{~g}$, manganese sulfate $0.15 \mathrm{~g}$, dibasic calcium phosphate $2.5 \mathrm{~g}$, cobalt sulfate $1 \mathrm{mg}$, sodium selenite $1.5 \mathrm{mg}, \mathrm{KCl} 0.45 \mathrm{~g}, \mathrm{NaCl} 0.2 \mathrm{~g}$.

$\|$ Includes lignin, non-starch polysaccharides and oligosaccharides and were estimated as follows: $\mathrm{N}$-free extracts $(\mathrm{g} / \mathrm{kg})=100-(\mathrm{ash}+\mathrm{crude}$ protein $+\mathrm{crude}$ fat + starch).

ๆ Calculated from apparent digestibility coefficient data of the digestibility experiment (Table 4).

${ }_{\star \star}$ Calculated from the glycosinolate content of the rapeseed meals (see Table 1). 
diet, each sample corresponding to a pool of $7 \mathrm{~d}$ of defecation from each tank) were analysed for $\mathrm{Cr}_{2} \mathrm{O}_{3}$, protein, fat, energy, ash and $\mathrm{P}$ content. The ADC values of DM, nutrients and energy in the different experimental diets were calculated according to Maynard \& Loosly (1969):

$$
\begin{gathered}
\text { ADC of DM }=1-\left(\text { dietary } \mathrm{Cr}_{2} \mathrm{O}_{3} / \text { faecal } \mathrm{Cr}_{2} \mathrm{O}_{3}\right), \\
\text { ADC of nutrient or energy }=1-\left(\text { dietary } \mathrm{Cr}_{2} \mathrm{O}_{3} / \text { faecal } \mathrm{Cr}_{2} \mathrm{O}_{3}\right) \\
\times(\text { faecal nutrient or energy/dietary nutrient or energy }) .
\end{gathered}
$$

\section{Growth study}

Fifteen outdoor tanks (500 litres) were used at the INRA experimental fish farm (Donzacq, Landes, France) during spring 1995. Tanks were supplied with spring water $\left(17 \pm 1^{\circ}\right.$, flow rate 10 litres $\left./ \mathrm{min}\right)$. Fifty rainbow trout with an average body weight of $20 \mathrm{~g}$ were randomly allocated to each tank. After a 1-week adaptation period, one of the five diets were fed to each group of three tanks of fish for 9 weeks. Food was distributed twice a day by hand, to apparent satiety. Fish were weighed and the voluntary feed intake was recorded every 3 weeks.

At the end of the growth study, a series of tissue and blood samplings were performed on fish fed on the respective diets. In order to minimize the possibility of time and tank effects, samples of fish were taken from the tanks at two different times over a $4 \mathrm{~d}$ period (from day 70 until day 73), according to a randomly scheduled sequence. In addition, to keep disturbance to the fish at minimum, the same tanks were never sampled more than once every $24 \mathrm{~h}$ and nocturnal samplings were conducted without using any light. In total, this series of sampling resulted in five fish per tank $8 \mathrm{~h}$ before the morning meal (at 00.00 hours) and five others $4 \mathrm{~h}$ after the morning meal (at 12.00 hours), i.e. thirty fish per dietary treatment.

Blood samples of all sampled fish were obtained from vessels near the caudal peduncle using a heparinized syringe. Blood was immediately centrifuged and plasma was stored at $-20^{\circ}$. The liver, the brain and the kidney of all sampled fish were dissected following blood sampling, frozen in liquid $\mathrm{N}_{2}$, and stored at $-80^{\circ}$. Ten additional fish were taken on day 73 at 12.00 hours from both control and the R2-500 dietary treatment for histological studies. The lower jaw was dissected from each fish immediately after blood sampling, and fixed in Bouin's fluid.

\section{Chemical analysis of ingredients, diets, faeces and whole body}

Whole fish body samples (three pools of ten fish from the beginning of the experiment and one pool of five fish per tank at the end of the experiment) were homogenized and freeze-dried. Analyses of composition of ingredients, diets, freeze-dried faeces and whole-body samples were made following the usual procedures: DM after drying at $105^{\circ}$ for $24 \mathrm{~h}$; ash by combustion at $550^{\circ}$ for $12 \mathrm{~h}$; protein $(\mathrm{N} \times 6.25)$ by the Kjeldahl method after acid digestion; gross energy in an adiabatic bomb calorimeter (IKA C-4000, Cofralab, Colomiers, France); fat after extraction with light petroleum $\left(40^{\circ}-60^{\circ}\right)$ by the Soxhlet method and total $\mathrm{P}$ by spectrophotometric analysis of the phosphovanadomolybdate complex after mineralization and acid digestion (ISO/DIS 6491 method). Phytic acid content was determined according to Davies \& Reid (1979) (analysis performed by the Department of Animal Production Sciences, University of Udine, Italy). Starch was measured by an enzymic method (Thivend et al. 1972) using glucoamylase and glucose oxidase. $\mathrm{Cr}_{2} \mathrm{O}_{3}$ in the diet and faeces was determined according to Bolin et al. (1952). For essential amino acids, the ingredients were hydrolysed with $6 \mathrm{M}-\mathrm{HCl}$ at $110^{\circ}$ for $24 \mathrm{~h}$ and the chromatographic separation and analysis of the amino acids were performed after orthophthaldehyde (Sigma P 1378, St Quentin, France) derivatization of amino acids using HPLC (HPLC-Varian Model 5000, Varian, Limerick, Ireland, $\mathrm{C}_{18}$ Aminotag column, Varian, Limerick, Ireland) following a modified procedure of Gardner \& Miller (1980).

\section{Thyroid status}

Assay for thyroid hormones in plasma. Plasma thyroid hormone $\left(\mathrm{T}_{4}\right.$ and $\left.\mathrm{T}_{3}\right)$ levels were measured with a radioimmunoassay described by Boeuf \& Prunet (1985) and modified by Martinez et al. (1995). The detection limits for the $\mathrm{T}_{4}$ and $\mathrm{T}_{3}$ radioimmunoassays were 1.25 and $0.62 \mathrm{ng} / \mathrm{ml}$ respectively. The specific binding obtained was $46 \%$ for $\mathrm{T}_{4}$ and $67 \%$ for $\mathrm{T}_{3}$, and the non-specific binding was $10 \%$ for $\mathrm{T}_{4}$ and $9 \%$ for $\mathrm{T}_{3}$. These percentages were estimated at a hormone level of $80 \mathrm{ng} / \mathrm{ml}$. The intra-assay CV was $10 \%$ for both $\mathrm{T}_{4}$ and $\mathrm{T}_{3}$.

Deiodinase assay. A previous study (Mol et al. 1998) allowed us to determine the different types of deiodinases present in rainbow trout (D1, D2 and D3) and the tissues with the highest level of enzymic activity (liver, brain and kidney). Deiodinase activities were measured as described in that paper.

The microsomal fractions were prepared as described previously (Mol et al. 1998). Tissues were homogenized in five volumes of buffer (0.25 M-sucrose, $10 \mathrm{mM}$-HEPES, $\mathrm{pH} 7 \cdot 0,1 \mathrm{mM}-1$,4-dithiothreitol) and centrifuged for $20 \mathrm{~min}$ $\left(4^{\circ}\right.$ at $\left.25000 \mathrm{~g}\right)$. The supernatant fraction was then centrifuged for $60 \mathrm{~min}\left(4^{\circ}\right.$ at $\left.100000 \mathrm{~g}\right)$. The resulting pellet and fluffy upper layer were resuspended together in three volumes of buffer (0.1 M-phosphate, $\mathrm{pH} 7 \cdot 0,2 \mathrm{mM}$-EDTA, $1 \mathrm{mM}$-1,4-dithiothreitol), snap-frozen in portions and stored at $-80^{\circ}$. All procedures were carried out on ice. Protein concentrations were determined with the BCA protein assay reagent (Bio-Rad, Nazareth, Belgium) using bovine serum albumin as a standard.

D1 activity was measured in the kidney ( $n 30$ per dietary treatment), while D2 activity was measured in the liver ( $n 30$ per dietary treatment) and D3 activity was measured in the brain (brains of the fish sampled in each tank and at each sampling time are pooled, $n 6$ per dietary treatment). In brief, an adequate amount of microsomal protein $(1 \mathrm{mg} / \mathrm{ml}$ for each assay except in the case of liver D2: $0.25 \mathrm{mg} / \mathrm{ml}$ ) suspended in sodium phosphate buffer ( $0.1 \mathrm{M}, 2 \mathrm{mM}$-EDTA, $1 \mathrm{mM}$-1,4-dithiothreitol, $\mathrm{pH}$ 7.1) was incubated with a similar amount of substrate-cofactor solution (kidney D1 and liver D2: $1 \mathrm{~h}$ at $30^{\circ}$; brain D3: $1 \mathrm{~h}$ at $37^{\circ}$ ). $3.70 \mathrm{kBq}$ of the preferred radioactive $\left({ }^{125} \mathrm{I}\right)$ substrate was added in the substrate-cofactor solution (D1: $\mathrm{rT}_{3}(0 \cdot 1 \mu \mathrm{M}) ; \mathrm{D} 2: \mathrm{T}_{4}$ $\left.(1 \mathrm{nM}) ; \mathrm{D} 3: \mathrm{T}_{3}(10 \mathrm{nM})\right)$ and 1,4-dithiothreitol as cofactor 
(30 mM for D1; $50 \mathrm{~mm}$ for D2; $10 \mathrm{mM}$ for D3 in brain). Each sample was tested in duplicate, together with blanks, containing no protein, to measure non-enzymic degradation of the tracer. For the D1 and D2 enzyme assays, the reaction was stopped on ice by addition of bovine serum albumin $(50 \mathrm{~g} / \mathrm{l})$ and release of radioiodine by ORD of outer ringlabelled $\mathrm{rT}_{3}$ or $\mathrm{T}_{4}$ was estimated ( $\gamma$-counter, Hewlett-Packard, Groningen, The Netherlands) after precipitation of protein-bound iodothyronines with TCA $(100 \mathrm{~g} / \mathrm{l})$. For the D3 assay, reactions were stopped by addition of methanol and iodothyronine products were analysed by HPLC (Eelkman Rooda et al. 1989). The deiodinase activity is expressed as fmol substrate converted/mg protein per minute.

Thyroid follicle histology. Lower jaws were kept in Bouin's fluid for $18 \mathrm{~d}$. Jaws were decalcified in TCA $(50 \mathrm{~g} / \mathrm{l})$ for $7 \mathrm{~d}$, and after dehydration, the tissues were embedded in paraffin. Serial sections $(20 \mu \mathrm{m})$ of longitudinally-oriented lower jaws were made. One section out of ten was kept and stained according to Gabe (1968) by alcian blue (pH 2.6), Groat's haematoxylin and orange G. Histological examinations were made with a semi-automatic image analyser (VIDS-IV, Systèmes Analytiques, Compiègne, France). The volume occupied by the total thyroid follicles was calculated from areas observed on serial sections in seven fish. The quantity of follicles was estimated using a screen (ninety-six equidistant dots; magnification $\times 60$ ) which was moved over the entire area of each section. The number of dots situated on a follicle was counted and the corresponding volume $\left(\mathrm{mm}^{3}\right)$ was calculated by:

$$
\mathrm{V}=(\mathrm{N} \times \mathrm{S} \times \mathrm{E} \times \mathrm{C}) / 96,
$$

where $\mathrm{N}$ is the total number of the dots counted on the successive sections in each fish, $\mathrm{S}$ is the surface area of the screen $\left(\mathrm{mm}^{2}\right), 96$ is number of dots in the screen, $E$ is the thickness of the sections $(\mathrm{mm}), \mathrm{C}$ is the interval between two sections examined $(\mathrm{mm})$.

The mean height (distance between basal and apical face of cell; magnification $\times 500$ ) of 100 follicle epithelial cells was also measured in ten fish.

\section{Data analysis}

The effect of dietary treatments was analysed by one-way ANOVA $(P<0.05)$, and when appropriate, means were compared by the Tukey's multiple range test. When only two series of data were compared, the Student's $t$ test was performed $(P<0 \cdot 05)$. Pearson's correlation coefficients $\left(r_{\mathrm{S}} ; P<0.005\right)$ or regression coefficients $\left(r^{2} ; P<0.05\right)$ were used to assess the relationship between the different variables.

\section{Results}

\section{Digestibility of components of experimental diets}

The ADC of protein and fat were significantly lower in the R2-500 diet than in the other RM-based diets (Table 4). However, it was not different from the control diet. A significant inverse relationship was found between the GLS content of the diet and the ADC of the DM $\left(r^{2} 0.97 ; P<0.05\right)$. The ADC of energy was significantly lower in the R2-500 diet compared with all the other diets. The ADC of starch was high $(>0.88)$, and its variation was associated mainly with the dietary starch content $\left(r^{2} 0.86 ; P<0 \cdot 05\right)$. The ADC of $\mathrm{P}$ was low in all diets $(<0 \cdot 34)$ and especially with the R2-500 diet which contained the highest quantity of RM2.

\section{Growth performance, feed intake and feed efficiency}

The incorporation of RM in the diet caused a significant decrease in growth performance already after three weeks of feeding (Fig. 1(A)). The voluntary feed intake was adversely affected only over the first 3 weeks of feeding (Fig. 1(B)). After 6 weeks the feed intake of groups fed on the RM-based diet was similar to, or greater than that of fish fed on the control diet. The decrease in daily growth index (Table 5) was accompanied by a decrease in feed efficiency. Taking into account the different levels of dietary incorporation of rapeseed meal, these decreases were stronger with RM2, containing a higher amount of GLS, than with the heattreated one (RM1). When the daily growth index and the feed efficiency were plotted against GLS intake (see Fig. 2 for feed efficiency), there was a strong decrease even at a low level of GLS intake (30-47 $\mu \mathrm{mol} / \mathrm{kg}$ average-fish-bodyweight and per d), with a plateau up to an intake level of $242 \mu \mathrm{mol} / \mathrm{kg}$ average-body-weight per $\mathrm{d}$ and a further decrease in daily growth index and feed efficiency was observed for higher levels of GLS intake $(422 \mu \mathrm{mol} / \mathrm{kg}$ average body weight per d).

Table 4. Apparent digestibility coefficients of the nutrients and energy in the experimental diets by rainbow trout (Mean values and mean squared errors for forty fish per group)

\begin{tabular}{|c|c|c|c|c|c|c|c|}
\hline & \multicolumn{5}{|c|}{ Diets* } & \multirow{2}{*}{$\begin{array}{l}\text { MSE between } \\
\text { groups }\end{array}$} & \multirow{2}{*}{$\begin{array}{l}\text { MSE within } \\
\text { groups }\end{array}$} \\
\hline & Control & $\mathrm{R} 1-300$ & $\mathrm{R} 1-500$ & $\mathrm{R} 2-300$ & $\mathrm{R} 2-500$ & & \\
\hline Dry matter & $0.78^{c}$ & $0.76^{c}$ & $0.76^{c}$ & $0.73^{b}$ & $0.69^{a}$ & 0.213 & 0.009 \\
\hline Protein & $0.89^{a b}$ & $0.90^{b}$ & $0.90^{b}$ & $0.90^{b}$ & $0.86^{a}$ & 0.055 & 0.014 \\
\hline Fat & $0.91^{a b}$ & $0.94^{b}$ & $0.95^{b}$ & $0.93^{b}$ & $0.86^{a}$ & 0.254 & 0.068 \\
\hline Gross energy & $0.84^{b}$ & $0.83^{b}$ & $0 \cdot 81^{b}$ & $0.81^{b}$ & $0.78^{a}$ & 0.109 & 0.016 \\
\hline Starch & $0.88^{a}$ & $0.94^{b}$ & $0.99^{c}$ & $0.91^{b}$ & $0.98^{c}$ & 0.418 & 0.017 \\
\hline Phosphorus & $0.33^{b}$ & $0.33^{b}$ & $0.34^{b}$ & $0.34^{b}$ & $0 \cdot 15^{a}$ & 1.414 & 0.226 \\
\hline
\end{tabular}

MSE, mean squared error.

${ }_{a, b, c}$ Mean values within a row with unlike superscript letters were significantly different (one-way ANOVA and Tukey's multiple range test; $P<0.05)$.

* For details of composition of diets see Table 3; the glucosinolate content of the diets were (mol/kg dry matter): R1-300 1.4, R1-500 2.3, R2$30011 \cdot 6, \mathrm{R} 2-500$ 19.3. 

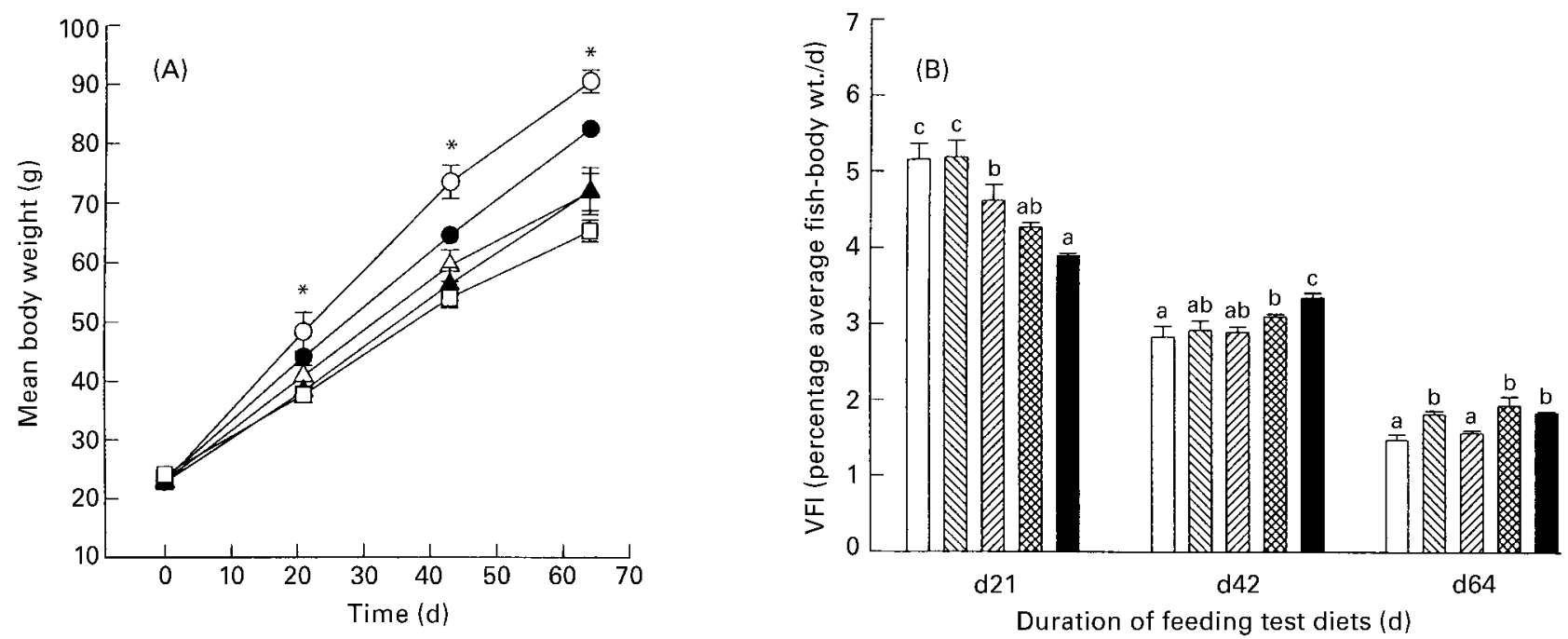

Fig. 1. Effect of diets containing 0,300 or $500 \mathrm{~g}$ rapeseed meal on (A) mean body weight and (B) voluntary food intake (VFI) of rainbow trout. For details of the oil-extraction procedures used to prepare rapeseed meals 1 and 2 (R1 and R2) see p. 654, and for details of composition of diets

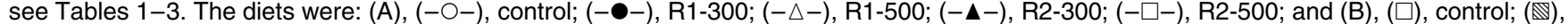
R1-300; (四), R1-500; (网), R2-300; (ם), R2-500. Values are means ( $n$ 150) with standard deviations shown by vertical bars. ${ }^{*} P<0.05$ (one-way ANOVA); ${ }^{a, b, c}$ mean values with unlike superscript letters were significantly different (one-way ANOVA and Tukey's multiple range test).

Protein and energy retention were significantly lower in fish fed on the R2-500 diet than in those fed on the other diets (Table 5). P retention was significantly lower in all fish fed on the RM-based diets than in fish fed on the control diet irrespective of the kind of RM and the level of incorporation. The decrease in $\mathrm{P}$ retention was correlated with an increase in $\mathrm{RM}$ intake $\left(r_{\mathrm{S}}-0.80 ; P<0.001\right)$.

\section{Thyroidal status}

No significant effect of sampling time (diurnal and nocturnal samplings) was detected in plasma levels of $\mathrm{T}_{3}, \mathrm{~T}_{4}$, and deiodinase activities. Ingestion of RM-based diets induced a significant decrease (about $40 \%$ ) of the plasma $\mathrm{T}_{3}$ level and an even more important decrease (about $80 \%$ ) of the plasma $\mathrm{T}_{4}$ level, regardless of the RM used and its level of incorporation (Fig. 3).

As shown in Table 6 , the $\mathrm{T}_{3}: \mathrm{T}_{4}$ ratio was considerably higher (about $300 \%$ ) in fish fed on RM-based diets than in fish fed on the control diet. D2 activity in the liver and D1 activity in the kidney were increased by $600 \%$ and $50 \%$ respectively, while D3 activity was inhibited in the brain (about $60 \%$ ) in fish fed on RM-based diets.

Changes in thyroid follicle activity, as determined through histological studies, are shown in Figs 4 and 5 and Table 6. The thyroid follicles were mainly located in the lower jaw of trout, scattered alongside the ventral aorta near the first brachial arches (Fig. 4). The volume of total thyroid tissue was significantly higher in fish fed on the R2-500 diet (about $270 \%$ ) than in fish fed on the control diet (Fig. 5(A)

Table 5. Growth, feed intake, nutrient and energy retention of rainbow trout fed on the experimental diets for $64 \mathrm{~d}+$ (Mean values and mean squared errors for 150 fish per group)

\begin{tabular}{|c|c|c|c|c|c|c|c|}
\hline & \multicolumn{5}{|c|}{ Diets* } & \multirow{2}{*}{$\begin{array}{l}\text { MSE between } \\
\text { groups }\end{array}$} & \multirow{2}{*}{$\begin{array}{l}\text { MSE within } \\
\text { groups }\end{array}$} \\
\hline & Control & $\mathrm{R} 1-300$ & $R 1-500$ & $\mathrm{R} 2-300$ & $\mathrm{R} 2-500$ & & \\
\hline \multicolumn{8}{|l|}{ Growth performance and feed utilization } \\
\hline Final body weight $(\mathrm{g})$ & $90 \cdot 6^{d}$ & $82 \cdot 5^{c}$ & $71.9^{b}$ & $71 \cdot 8^{a b}$ & $65 \cdot 2^{a}$ & $302 \cdot 4$ & $13 \cdot 2$ \\
\hline Biomass gain (\% IBW) & $284^{d}$ & $252^{c}$ & $214^{\mathrm{b}}$ & $208^{b}$ & $167^{a}$ & 6033 & 208 \\
\hline Daily growth index $\ddagger$ & $2 \cdot 6^{d}$ & $2 \cdot 3^{c}$ & $2 \cdot 1^{b}$ & $2 \cdot 0^{\mathrm{b}}$ & $1.8^{a}$ & 0.295 & 0.004 \\
\hline Voluntary feed intake (\% of body weight/d)§ & $2 \cdot 0^{\mathrm{a}}$ & $2 \cdot 1^{b c}$ & $2 \cdot 1^{\mathrm{ab}}$ & $2 \cdot 0^{\mathrm{ab}}$ & $2 \cdot 2^{c}$ & 0.016 & 0.002 \\
\hline Feed efficiency ratioll & $0.99^{d}$ & $0 \cdot 86^{c}$ & $0 \cdot 80^{b}$ & $0.81^{b c}$ & $0.68^{a}$ & 0.0374 & 0.0009 \\
\hline \multicolumn{8}{|l|}{ Retention (\% of intake) } \\
\hline Protein & $36 \cdot 0^{\mathrm{b}}$ & $31 \cdot 7^{\mathrm{ab}}$ & $32 \cdot 5^{b}$ & $32 \cdot 3^{b}$ & $27 \cdot 1^{a}$ & $30 \cdot 5$ & $8 \cdot 0$ \\
\hline Energy & $38.6^{b}$ & $36 \cdot 6^{b}$ & $34.9^{b}$ & $35 \cdot 6^{b}$ & $27 \cdot 6^{a}$ & $51 \cdot 8$ & $7 \cdot 8$ \\
\hline Phosphorus & $28 \cdot 8^{b}$ & $22 \cdot 0^{a}$ & $21 \cdot 2^{a}$ & $21 \cdot 8^{a}$ & $19 \cdot 1^{a}$ & $40 \cdot 2$ & $6 \cdot 4$ \\
\hline
\end{tabular}

MSE, mean squared error; IBW, initial body weight.

$\mathrm{a}, \mathrm{b}, \mathrm{c}, \mathrm{d}$ Mean values within a row with unlike superscript letters were significantly different (one-way ANOVA and Tukey's multiple range test; $P<0.05$ ).

${ }^{*}$ For details of composition of diets see Table 3; the glucosinolate content of diets were ( $\mu \mathrm{mol} / \mathrm{g}$ dry matter); R1-300 1.4, R1-500 2.3, R2-300 11.6, R2-500 19.3.

$\dagger$ The initial body weight of the trout was $23 \cdot 2(S D 0.6) \mathrm{g}$. The fish were kept at a temperature of $17 \pm 1^{\circ}$.

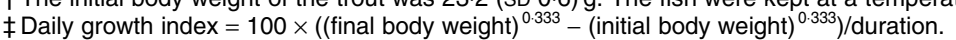

$\S$ Voluntary feed intake $=100 \times$ dry feed intake $(\mathrm{g}) /($ (initial body weight + final body weight $) / 2) \times$ duration.

$\|$ Feed efficiency ratio = wet wt. gain $(\mathrm{g})$ : dry feed intake $(\mathrm{g})$.

ๆRetention $=100 \times($ final body weight $\times$ final carcass nutrient content - initial body weight $\times$ initial carcass nutrient content $) /$ nutrient intake. 


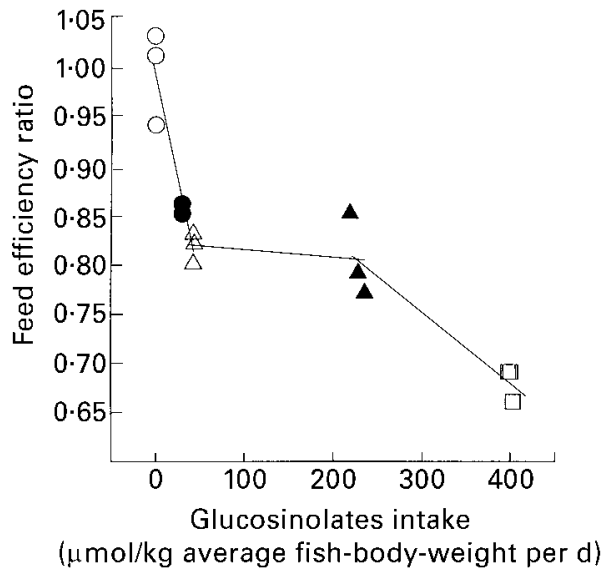

Fig. 2. Relationship between glucosinolate intake and feed efficiency ratio in rainbow trout fed on diets containing 0,300 or $500 \mathrm{~g}$ rapeseed $\mathrm{meal} / \mathrm{kg}$ over the whole growth period of $64 \mathrm{~d}$. For details of the oilextraction procedures used to prepare rapeseed meals 1 and 2 (R1 and R2) see p. 654, and for details of the composition of the diets see Tables 1-3. Each symbol represents one replicate. The diets were:

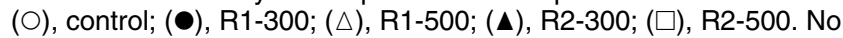
statistical analysis of the three straight lines drawn on the figure was made due to the small number of data.

and 5(B), Table 6). The height of the epithelial follicle cells was significantly higher $(200 \%)$ in fish fed on the R2-500 diet, indicating increased follicle activity (Fig. 5(C) and 5(D)).

\section{Discussion}

Detailed information on the goitrogenic activity of dietary $\mathrm{RM}$ in birds and mammals, including human subjects is available (see Mawson et al. 1994b). Data from terrestrial animals as well as from fish (Yurkowski et al. 1978; Higgs et al. 1982; Hardy \& Sullivan, 1983; Hilton \& Slinger, 1986; Leatherland et al. 1987; Hossain \& Jauncey, 1988; Teskeredzic et al. 1995; Webster et al. 1997) have shown the role of GLS in thyroidal disturbances. In fact, the toxicity is not directly caused by the GLS, but by the GLS

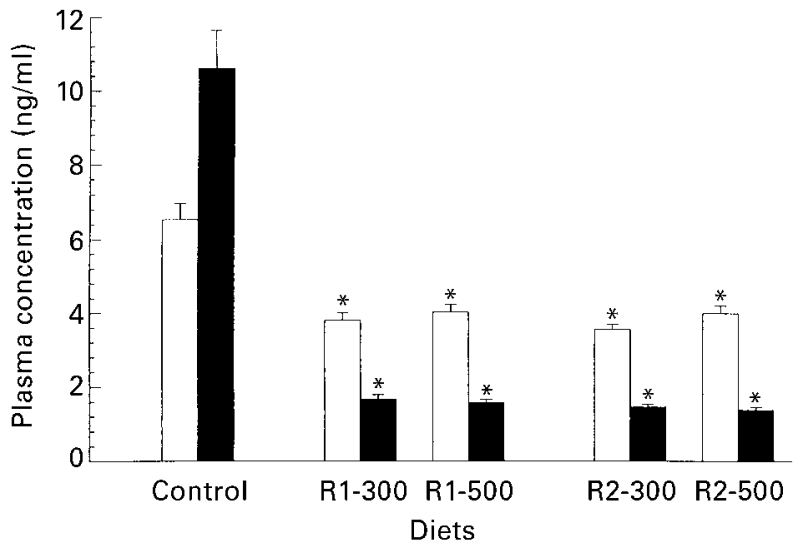

Fig. 3. Plasma concentrations of triiodothyronine ( $\square$ ) and thyroxine (घ) in rainbow trout fed on diets containing 0,300 or $500 \mathrm{~g}$ rapeseed meal $/ \mathrm{kg}$ at the end of the experimental feeding period for each diet. For details of the oil-extraction procedures used to prepare rapeseed meals 1 and 2 (R1 and R2) see p. 654, and for details of the composition of the diets see Tables 1-3. Values are means ( $n 40$ per group) with standard deviations represented by vertical bars. Mean values were significantly different from those of the control group: ${ }^{\star} P<0.05$ (one-way ANOVA and Tukey's multiple range test).

breakdown products such as isothiocyanates, thiocyanate anions, oxazolidinethiones and nitriles, mainly as a result of the activity of myrosinase, a specific plant hydrolytic enzyme. In intact plant tissues, the enzyme is stored separately from the GLS substrates in specific cells (idioblasts) (Grob \& Matile, 1979). Contact between the two is a result of mechanical injury of the plant tissue as it occurs during the processing of RM.

Our data indicate that the content of intact GLS in the diet in itself may not be a good indicator of the potential deleterious effects of RM in fish. To reduce the GLS content and to denature the myrosinase during the processing of meal, it is necessary to apply high temperatures during the oil-extraction process. The difficulty then is to succeed in the degradation of the GLS without the production of toxic by-products. The two RM used in our study have been

Table 6. Effects of dietary glucosinolate intake on thyroid function in rainbow trout: thyroid follicular activity, triiodothyronine : thyroxine ratio and peripheral deiodinase activity

(Mean values and mean squared errors)

\begin{tabular}{|c|c|c|c|c|c|c|c|}
\hline & \multicolumn{5}{|c|}{ Diets $^{*}$} & \multirow{2}{*}{$\begin{array}{l}\text { MSE between } \\
\text { groups }\end{array}$} & \multirow{2}{*}{$\begin{array}{l}\text { MSE withir } \\
\text { groups }\end{array}$} \\
\hline & Control & $\mathrm{R} 1-300$ & $\mathrm{R} 1-500$ & $\mathrm{R} 2-300$ & $\mathrm{R} 2-500$ & & \\
\hline \multicolumn{8}{|l|}{ Thyroid follicular activity $\dagger$} \\
\hline Thyroid volume $\left(\mathrm{mm}^{3}\right)$ & $2 \cdot 8^{\mathrm{a}}$ & ND & ND & ND & $10 \cdot 3^{b}$ & 200 & 46 \\
\hline Epithelial cell height $(\mu \mathrm{m})$ & $4 \cdot 3^{a}$ & ND & ND & ND & $13 \cdot 0^{b}$ & 339.92 & 0.57 \\
\hline $\mathrm{T}_{3}: \mathrm{T}_{4}$ & 0.6 & $2 \cdot 3$ & $2 \cdot 6$ & 2.4 & $2 \cdot 9$ & & \\
\hline \multicolumn{8}{|c|}{ Deiodinase activities (fmol/mg protein per $\mathrm{min}$ ) $\ddagger$} \\
\hline D1 in kidney ( $\mathrm{fmol} \mathrm{rT}_{3}$ ) & $145 \cdot 4^{\mathrm{a}}$ & $224.9^{b c}$ & $262 \cdot 0^{d}$ & $206 \cdot 2^{b}$ & $232 \cdot 3^{\mathrm{c}}$ & $45 \cdot 8$ & 1.4 \\
\hline D2 in liver (fmol $T_{4}$ ) & $10 \cdot 1^{\mathrm{a}}$ & $72 \cdot 9^{b}$ & $73 \cdot 2^{b}$ & $71 \cdot 4^{\mathrm{b}}$ & $72 \cdot 0^{b}$ & 37306 & 82 \\
\hline D3 in brain ( $\mathrm{fmol} \mathrm{T}_{3}$ ) & $22 \cdot 2^{b}$ & $8 \cdot 3^{a}$ & $9 \cdot 3^{a}$ & $10 \cdot 7^{a}$ & $6 \cdot 7^{\mathrm{a}}$ & 216 & 43 \\
\hline
\end{tabular}

MSE, mean squared error; ND, not determined; $T_{3}$, triiodothyronine; $T_{4}$, thyronine; $r T_{3}$, reverse triiodothyronine; $D$, deiodinase.

${ }_{a, b, c}$ Mean values within a row with unlike superscript letters were significantly different (one-way ANOVA and Tukey's multiple range test or Student's $t$ test; $P<0.05$ ). ${ }^{*}$ For details of the composition of diets see Table 3; the glucosinolate content of the diets were (mol/kg dry matter): R1-300 1.4, R1-500 2.3, R2-300 11.6, R2-500 19.3. $\dagger$ Thyroid volume was measured on seven fish and the epithelial cell height on ten fish.

$\ddagger n 15$, except for deiodinase 3 activity in the brain where $n 3$ (pooled). 


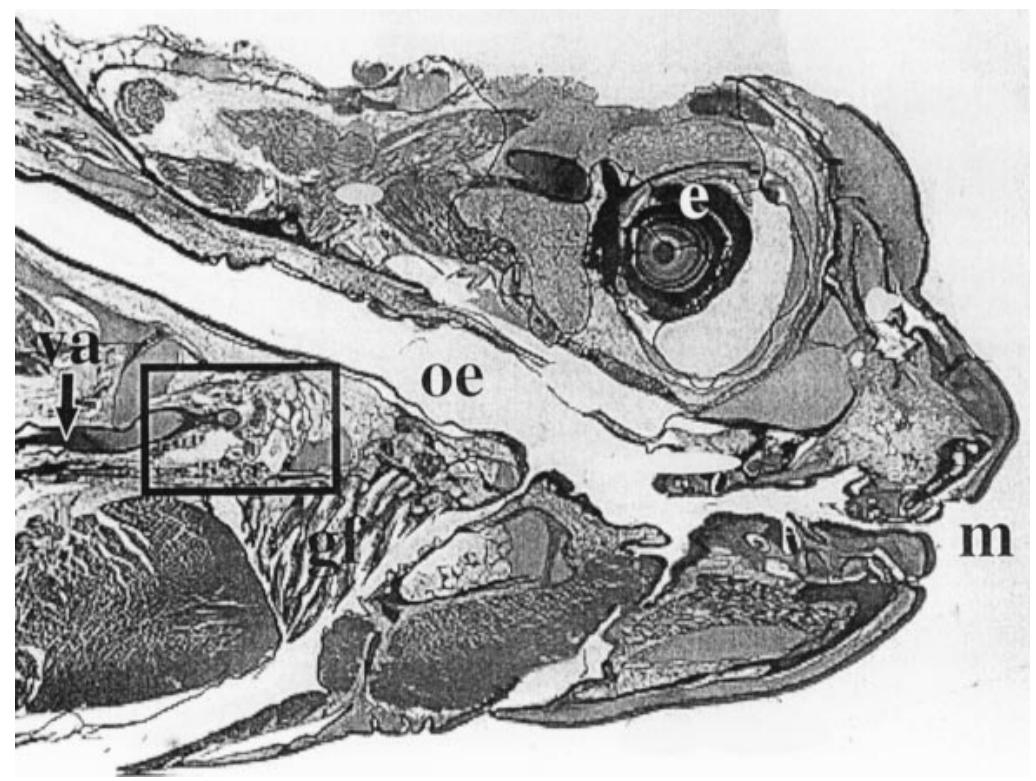

Fig. 4. Sagittal section of a rainbow trout head after a period of starvation (1 week; hypothyroidal fish). Large follicles are scattered throughout a highly vascularized region of the lower jaw adjacent to the ventral aorta (see in the square). The histological features suggest a very low activity of the follicles: very large follicles with large, homogenous colloids. va, Section of the ventral aorta; gf, section of gill filaments; oe, oesophagus; $m$, mouth; e, eye. Magnification $\times 5$.
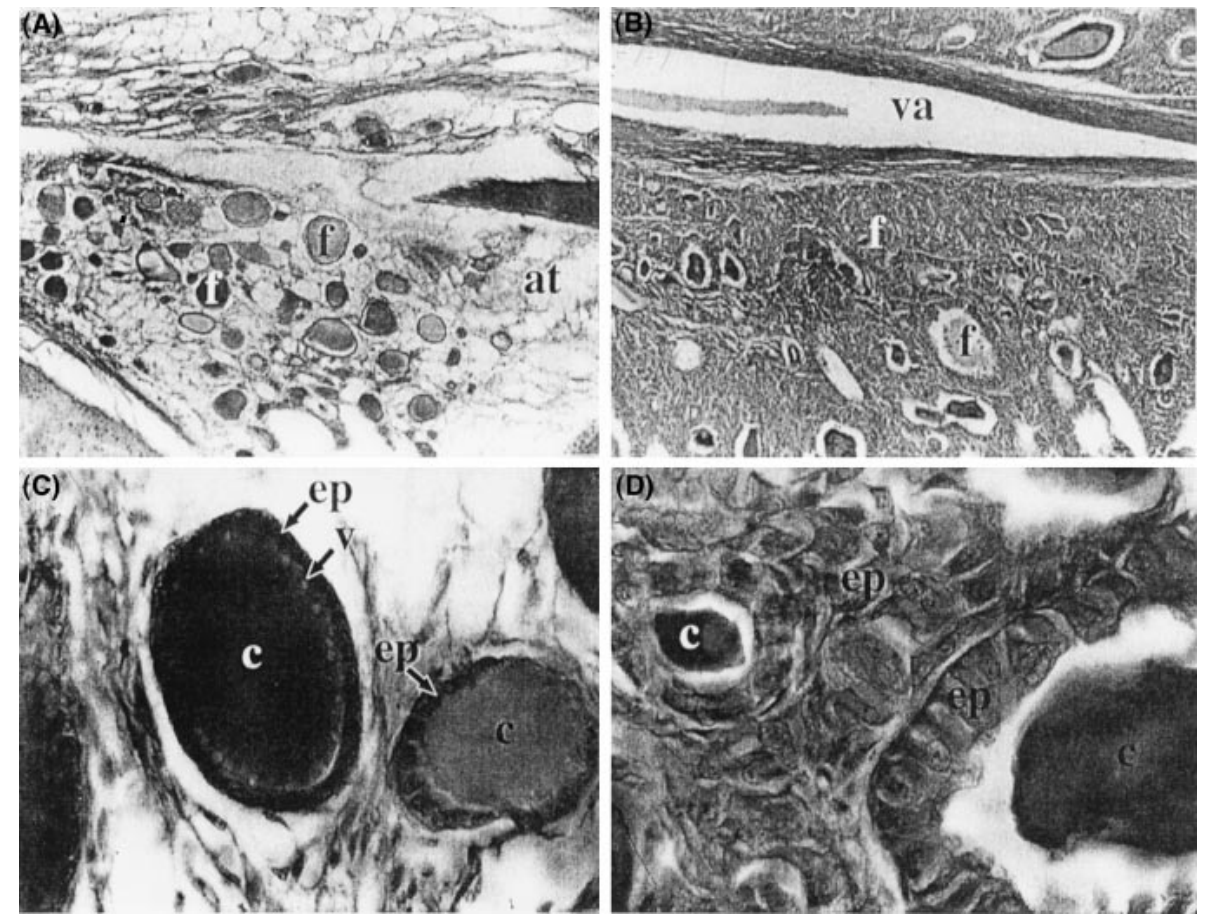

Fig. 5. Thyroid follicles in rainbow trout. (A) Thyroid follicles in a rainbow trout fed on a control diet for $73 \mathrm{~d}$. The thyroidal tissue is not very dense, the follicles (f) are spread into adipose tissue (at) (magnification $\times 60$ ). (B) Thyroid follicles of a rainbow trout fed on a diet containing $500 \mathrm{~g}$ rapeseed meal (R2)/kg diet (R2-500) for $73 \mathrm{~d}$. Thyroidal tissue is very dense (f) and the proximity to the ventral aorta $(\mathrm{va})$ is evident (magnification $\times 60$ ). (C) Unstimulated thyroid tissue of a rainbow trout fed on a control diet for $73 \mathrm{~d}$. The follicle epithelial cells (ep) are cuboidal in appearance, and the colloid (c) within the lumen is homogenous. The nucleus : cytoplasm ratio of the epithelial cells is high. Vesiculation $(v)$ of the colloid is evident in this follicle (magnification $\times 500$ ). (D) Stimulated thyroid tissue of a rainbow trout fed on diet R2-500 for $73 \mathrm{~d}$. The follicle epithelial cells (ep) are very large and are columnar. The colloid (c) is partly or wholly depleted. The nucleus : cytoplasm ratio of the epithelial cells is small (magnification $\times 500$ ). For details of the oil-extraction procedure used to prepare R2 see p. 654, and for details of the composition of the diets see Tables 1-3. 
subjected to two different oil-extraction processes including different thermal conditions. In addition to the different quantities and profiles obtained in GLS, different quantities and profiles of active breakdown products could be obtained either during the process or later on if enough myrosinase remained active (Nugon-Baudon \& Rabot, 1994).

In this present study, a deleterious effect of dietary RM incorporation on thyroidal status and fish growth is shown, even at an incorporation level of $300 \mathrm{~g}$ heat treated $\mathrm{RM} / \mathrm{kg}$ diet with a very low content of GLS $(1.4 \mu \mathrm{mol} / \mathrm{g}$ diet $)$. In the previous studies on fish (Yurkowski et al. 1978; Higgs et al. 1982; Hardy \& Sullivan, 1983; Hilton \& Slinger, 1986; Leatherland et al. 1987; Hossain \& Jauncey, 1988; Teskeredzic et al. 1995; Webster et al. 1997), the dietary amount of toxic compounds was expressed either as the amount of intact GLS, as the amount of intact GLS plus GLS breakdown products or as the amount of GLS breakdown products alone. As a result, the lowest level of toxic compounds inducing thyroidal disturbance or growth depletion varied greatly between studies. Nevertheless, our results are generally in accordance with those obtained by Yurkowski et al. (1978), Hardy \& Sullivan (1983) and Leatherland et al. (1987) in rainbow trout, who determined a critical level of toxic compounds in the range of $1-2 \mathrm{~mol} / \mathrm{kg}$ diet using different types of processed RM. Amongst terrestrial animals, ruminants are considered to be less sensitive than singlestomached animals (for reviews see Mawson et al. 1994a, b): growth, feed intake and feed conversion are reduced by a dietary GLS content of approximately $3-4 \mathrm{~mol} / \mathrm{kg}$ diet in the rat, $0.6-3 \mathrm{~mol} / \mathrm{kg}$ in the young $\mathrm{pig}, 4-10 \mathrm{~mol} / \mathrm{kg}$ in growing poultry, and $7-15 \mathrm{~mol} / \mathrm{kg}$ in young calves; thyroid function is affected by dietary levels of $0.5-4 \mathrm{~mol} / \mathrm{kg}$ in the rat, $2-3 \mathrm{~mol} / \mathrm{kg}$ in swine, $1.4 \mathrm{~mol} / \mathrm{kg}$ in growing poultry, and $8 \mathrm{~mol} / \mathrm{kg}$ in calves.

Irrespective of the type of RM used, we observed the typical features corresponding to a hypothyroid condition in trout. Lower $\mathrm{T}_{3}$ and $\mathrm{T}_{4}$ levels were accompanied by thyroid tissue hyperactivity, i.e. an increase in the volume of the thyroid tissue and epithelial follicle cell height (hyperplasy and hypertrophy). Moreover, these cells became columnar with the colloid partly or completely depleted. Our results also clearly demonstrate an effect of the hypothyroidal condition on the in vitro deiodinase activities. In vitro $\mathrm{D} 2$ activity in the liver and D1 activity in the kidney were elevated, both offering the possibility for an increased $T_{3}$ production from the available $\mathrm{T}_{4}$ by ORD. In addition, there was a decrease in in vitro D3 activity in the brain, reducing the degradation of $\mathrm{T}_{3}$ by IRD. It is not easy to extrapolate to the in vivo situation, but these results suggest that deiodinases compensate for the lack of bioactive $\mathrm{T}_{3}$, as suspected earlier by Higgs et al. (1982) and Hardy \& Sullivan (1983) in fish and in terrestrial animals (Mawson et al. 1994b). The in vivo potential role of each enzyme in the adjustment of the plasma thyroid hormones levels is difficult to establish, because their activity depends on the substrate and cofactor availability, the intracellular $\mathrm{pH}$ and the temperature. Nevertheless, the response of the D3 activity in the brain, given the size of this organ, seems to be a localized response and acts probably to protect the brain against $T_{3}$ levels which are too low.

The relationship between hypothyroidism and poor growth is established in mammals including human subjects (Boyages et al. 1989; Hetzel, 1994). However, the relationship between the thyroid disturbances induced by the metabolites of GLS and growth performance of fish has not been clearly demonstrated. Indirect evidence was given by Leatherland et al. (1987), who showed that a dietary $\mathrm{T}_{3}$ supplement in trout fed on RM-based diets led to an improved growth performance. In the present study, the lower growth rate of fish fed on the RM-based diets compared with that of the control fish was accompanied by low feed utilization. When this effect is related to dietary GLS intake, data show two thresholds of sensitivity. Indeed, ingestion of very low amounts of GLS, corresponding to a dietary content of GLS of $1.4 \mathrm{~mol} / \mathrm{kg} \mathrm{DM}$, led to a decrease of both growth rate and feed efficiency, but this effect was not further exacerbated with increasing dietary GLS levels up to $11.6 \mathrm{~mol} / \mathrm{kg}$. However, a higher dietary content of GLS (19.3 mol/kg DM) led to a stronger decrease of growth and feed efficiency. But the hypothesis of the existence of these thresholds of sensibility cannot be assured with the present data, because first, the amount of toxic derivatives of GLS were not measured here, and second, the effect of the other antinutritional factors present in the two rapeseed meals tested must be taken into account. The poor growth performance observed could be due to: (1) thyroid disturbances caused by increased levels of GLS. It is known that thyroid hormones play a role in the regulation of fish growth through intermediary metabolism (metabolic utilization of energy, amino acids and possibly carbohydrates; see Leatherland, 1994). Besides, several authors (Harvey et al. 1988; Luo \& McKeown, 1991; Farchi-Pisanty et al. 1995; Melamed et al. 1995) have shown a thyroidal regulation of growth hormone metabolism, hypothyroid condition possibly leading to a decrease of GH release. As a matter of fact, a deleterious effect of isolated isothiocyanates on the digestive utilization of nutrients, together with thyroid disturbances, has been reported in carp (Cyprinus carpio) (Hossain \& Jauncey, 1988). In the rat (Bille et al. 1983; Vermorel \& Baudet, 1987; Roland et al. 1996), isolated progoitrine, sinigrin and sinalbine impaired also the thyroid metabolism and protein digestibility and retention. A low level of bioactive $T_{3}$ may interfere with the digestive capacities of trout, given the effect of a treatment with thyroid hormones on the digestive function of rats (Hodin et al. 1992) and of red sea bream (Chrysophrys major) (Woo et al. 1991). In our study, the digestibility of the DM, protein, lipid, energy and $\mathrm{P}$ was significantly reduced when the diet contained $500 \mathrm{~g}$ untreated $\mathrm{RM} / \mathrm{kg}$, i.e. with the higher content of GLS. Nutrient and energy retentions were also reduced in fish fed on this diet. In addition, results of the present study show a dissociation between plasma $T_{3}$ levels and growth. It seems that there was a threshold of thyroidal sensitivity to the GLS breakdown products even at an incorporation level of $300 \mathrm{~g}$ heat-treated $\mathrm{RM} / \mathrm{kg}$. Two major hypotheses can be formulated. First, the compensatory effects of hypertrophy of thyroidal tissue and of the deiodinase activities may result in sufficient circulating levels in $\mathrm{T}_{3}$ (about $4 \mathrm{ng} / \mathrm{ml}$ ) to support normal growth. In such case, the goitrogenic activity of GLS breakdown products would play a minor or no role at all in the poor growth performance observed. Second, thyroidal disturbance could 
only be partially responsible for the lower growth rate, and thus, the differential response would be due to the direct effects of other antinutritional factors; (2) a direct effect of GLS on feed utilization. Indeed, GLS can interfere with liver function, because they induce alterations of the hepatic detoxification system as shown in mammals (Rabot et al. 1993; Williamson et al. 1996). An increase of the weight of liver and kidneys related to the amount of GLS ingested has been shown in growing pigs (Bourdon \& Aumaître, 1990). However, no work conducted in fish clearly show this effect, and in the present study, no liver or kidney abnormality was observed in trout; (3) a high dietary fibre content as generally found in RM (Higgs et al. 1996). The dehulling of the rapeseed allows only a partial decrease in the fibre content, with average levels of acid detergent fibre and neutral detergent fibre both remaining at $124 \mathrm{~g} / \mathrm{kg}$ DM (A Quinsac and D Ribailler, personal communication). Hilton \& Slinger (1986) found that dietary fibre can depress mineral bioavailability as well as decrease the intestinal transit time, with consequent effects on digestibility of DM, energy and P; (4) a high content of phytic acid and/or tannins. The concentration of phytic acid in the two RM were high (42-44 g/kg DM), as generally found in this protein source $(24-57 \mathrm{~g} / \mathrm{kg}$ DM; Higgs et al. 1996). Elevated levels of these compounds are known to depress the mineral bioavailability as well as activity of digestive enzymes in fish (Spinelli et al. 1983). RM are also known to have a high tannin content (Fenwick, 1982), which can depress protein digestibility.

It is interesting to notice that in apparent contradiction of what is observed in terrestrial animals (Mawson et al. 1993) and also in a previous study with rainbow trout (Hilton \& Slinger, 1986), our data do not show that dietary incorporation of RM leads to a decrease in feed intake. It was only decreased during the first 3 weeks of feeding, but the fish quickly became accustomed. This might be related to reduced levels of tannins and sinapine, known to affect the organoleptic properties of this ingredient, in these new cultivars of rapeseed.

The findings of this present study show that, despite their low content of GLS, the rapeseed meals tested here cannot be used in practical rainbow trout diets at $300 \mathrm{~g} / \mathrm{kg}$ without deleterious effects. These data are in agreement with those of Hardy \& Sullivan (1983), Hilton \& Slinger (1986), Leatherland et al. (1987), Gomes \& Kaushik (1989), Abdou Dade et al. (1990), McCurdy \& March (1992) and Gomes et al. (1993). Despite an important compensatory effect through the deiodinases, the levels of $\mathrm{T}_{4}$ and $\mathrm{T}_{3}$ in the plasma were reduced. The lower growth performance observed, especially with the higher level of RM, could be caused by the concomitant effect of the hypothyroid condition, the direct action of GLS and the action of the other antinutritional factors.

\section{Acknowledgements}

This work has been partially supported by the CETIOM (Centre Technique Interprofessionnel des Oléagineux Métropolitains, Paris, France), by the UNIP (Union Nationale Interprofessionnelle des Plantes Riches en Protéines, Paris, France) and by the KU Leuven Onderzoeksraad (project OT/94/11). The authors gratefully acknowledge the skilled technical assistance of D. Blanc, J. Brèque, Y. Hontang, A. Le Roux, L. Noterdaeme, P. Peyrotte, F. Sandres, A. Sévère, F. Terrier, C. Vachot, W. Van Ham and F. Voets.

\section{References}

Abdou Dade B, Aguirre P, Blanc D \& Kaushik SJ (1990) Incorporation du colza 00 sous forme de tourteau ou d'amande dans les aliments de la truite arc-en-ciel (Oncorhynchus mykiss): performance zootechnique et digestibilité (Incorporation of rapeseed 00 , in the form of cattle cake, or almond in diets for rainbow trout (Oncorhynchus mykiss): zootechnical performance and digestibility). Bulletin Français de la Pêche et de la Pisciculture 317, 50-57.

Bell JM (1993) Factors affecting the nutritional value of canola meal: a review. Canadian Journal of Animal Science 73, 679697.

Bille N, Eggum BO, Jacobsen I, Olsen O \& Sorensen H (1983) Antinutritional and toxic effects in rats of individual glucosinolates (+/- myrosinases) added to a standard diet. Zeitschrift für Tierphysiologie, Tierernährung und Futtermittelkunde 49, 195210.

Boeuf G \& Prunet P (1985) Measurements of gill $\left(\mathrm{Na}^{+}-\mathrm{K}^{+}\right)$ATPase activity and plasma thyroid hormones during smoltification in Atlantic salmon (Salmo salar L.). Aquaculture 45, 111-119.

Bolin DW, King RP \& Klosterman EW (1952) A simplified method for the determination of chromic oxide $\left(\mathrm{Cr}_{2} \mathrm{O}_{3}\right)$ when used as an index substance. Science 116, 634-635.

Bourdon D \& Aumaître A (1990) Low-glucosinolate rapeseeds and rapeseed meals: effect of technological treatments on chemical composition, digestible energy content and feeding value for growing pigs. Animal Feed Science and Technology 30, 175191.

Boyages SC, Collins JK, Maberly GF, Jupp JJ, Morris J \& Eastman CJ (1989) Iodine deficiency impairs intellectual and neuromotor development in apparently normal persons: a study of rural inhabitants of north-central China. Medical Journal of Australia 150, 676-682.

Bunting ES (editor) (1981) Production and Utilization of Protein in Oilseed Crops. The Hague: Martinus Nijhoff.

Choubert G (1999) La digestibilité des nutriments chez les poissons: aspects de méthodologie. (Digestibility of nutrients by fish: methodological considerations). Cybium 23, Suppl., $113-125$.

Choubert G, De la Noue J \& Luquet P (1982) Digestibility in fish: improved device for the automatic collection of feces. Aquaculture 29, 185-189.

Davies NT \& Reid H (1979) An evaluation of the phytate, zinc, copper, iron and manganese contents of, and $\mathrm{Zn}$ availability from, soya-based textured-vegetable-protein meat-substitutes or meat-extenders. British Journal of Nutrition 41, 579-589.

Eelkman Rooda SJ, Otten MH, van Loon MAC, Kaptein E \& Visser TJ (1989) Metabolism of triiodothyronine in rat hepatocytes. Endocrinology 125, 2187-2197.

Farchi-Pisanty O, Hackett PBJ \& Moav B (1995) Regulation of fish growth hormone transcription. Molecular Marine Biology and Biotechnology 4, 215-223.

Fenwick GR (1982) The assessment of a new protein source rapeseed. Proceedings of the Nutrition Society 41, 277-288.

Gabe M (1968) Techniques Histologiques (Techniques in Histology). Paris: Masson.

Gardner WS \& Miller WH (1980) Reverse-phase liquid chromatography of amino acids after reaction with ophthalaldehyde. Analytical Biochemistry 101, 61-70.

Gomes EF, Corraze G \& Kaushik S (1993) Effects of dietary 
incorporation of a co-extruded plant protein (rapeseed and peas) on growth, nutrient utilization and muscle fatty acid composition of rainbow trout (Oncorhynchus mykiss). Aquaculture 113, 339_ 353.

Gomes EF \& Kaushik SJ (1989) Incorporation of lupin seed meal, colzapro or triticale as protein/energy substitutes in rainbow trout diets. In Proceedings of Third International Symposium on Feeding and Nutrition in Fish, pp. 315-324 [M Takeda and $\mathrm{T}$ Watanabe, editors]. Toba, Japan, August 28-September 1, 1989.

Grob K \& Matile P (1979) Vacuolar location of glucosinolate in horseradish root cells. Plant Scientific Letters 14, 327-335.

Hardy RW \& Sullivan CV (1983) Canola meal in rainbow trout (Salmo gairdneri) production diets. Canadian Journal of Fisheries and Aquatic Sciences 40, 281-286.

Harvey S, Scanes CG \& Klandorf H (1988) Thyrotrophin-releasing hormone induces growth hormone secretion in adult hypothyroid fowl. General and Comparative Endocrinology 69, 233-237.

Hetzel BS (1994) S.O.S. for a billion - the nature and magnitude of the iodine deficiency disorders. In S.O.S. for a Billion: The Conquest of Iodine Deficiency Disorders, pp. 1-26 [BS Hetzel and CS Pandav, editors]. Oxford University Press: Delhi.

Higgs DA, Dosanjh BS, Beames RM, Prendergast AF, Mwachireya SA \& Deacon G (1996) Nutritive value of rapeseed/canola protein products for salmonids. In Eastern Nutrition Conference, pp. 187-196 [N Kent and D Anderson, editors]. Dartmouth/ Halifax, Canada, May 15-17, 1996.

Higgs DA, McBride JR, Markert JR, Dosanjh BS, Plotnikoff MD \& Clarke WC (1982) Evaluation of Tower and Candle rapeseed (Canola) meal and Bronowski rapeseed protein concentrate as protein supplements in practical dry diets for juvenile chinook salmon (Oncorhynchus tshawytscha). Aquaculture 29, $1-31$.

Hilton JW \& Slinger SJ (1986) Digestibility and utilization of canola meal in practical-type diets for rainbow trout (Salmo gairdneri). Canadian Journal of Fisheries and Aquatic Sciences 43, 1149-1155.

Hodin RA, Chamberlain SM \& Upton MP (1992) Thyroid hormone differentially regulates rat intestinal brush border enzyme gene expression. Gastroenterology 103, 1529-1536.

Hossain MA \& Jauncey K (1988) Toxic effects of glucosinolate (allyl isothiocyanate) (synthetic and from mustard oilcake) on growth and food utilization in common carp. Indian Journal of Fisheries 35, 186-196.

Kühn ER, Mol KA \& Darras VM (1993) Control strategies of thyroid hormone monodeiodination in vertebrates. Zoological Science 10, 873-885.

Leatherland JF (1994) Reflections on the thyroidology of fishes: from molecules to humankind. Guelph Ichthyology Reviews 2 , $1-67$.

Leatherland JF, Hilton JW \& Slinger SJ (1987) Effects of thyroid hormone supplementation of canola meal-based diets on growth, and interrenal and thyroid gland physiology of rainbow trout (Salmo gairdneri). Fish Physiology and Biochemistry 3, $73-82$.

Leonard JL \& Visser TJ (1986) Biochemistry of deiodination. In Thyroid Hormone Metabolism, pp. 189-229 [G Henneman, editor]. New York, NY: Marcel Dekker Inc.

Luo D \& McKeown BA (1991) The effect of thyroid hormone and glucocorticoids on carp growth hormone-releasing factor (GRF)-induced growth hormone (GH) release in rainbow trout (Oncorhynchus mykiss). Comparative Biochemistry and Physiology 99A, 621-626.

McCurdy SM \& March BE (1992) Processing of canola meal for incorporation in trout and salmon diets. Journal of the American Oil Chemists Society 69, 213-220.
Martinez I, Dreyer B, Argersborg A, Le Roux A \& Boeuf G (1995) Effect of triiodothyronine and rearing temperature on growth and skeletal myosin heavy chain isoform transition during early development in salmonid (Salvelinus alpinus L.). Comparative Biochemistry and Physiology 112B, 717-725.

Mawson R, Heaney RK, Zdunczyk Z \& Kozlowska H (1993) Rapeseed meal-glucosinolates and their antinutritional effects. Part 1. Rapeseed production and chemistry of glucosinolates. Nährung 37, 131-140.

Mawson R, Heaney RZ, Zdunczyk Z \& Kozlowska H (1994a) Rapeseed meal-glucosinolates and their antinutritional effects. Part 3. Animal growth and performance. Nährung 38, 167-177.

Mawson R, Heaney RK, Zdunczyk Z \& Kozlowska H (1994b) Rapeseed meal-glucosinolates and their antinutritional effects. Part 4. Goitrogenicity and internal organs abnormalities in animals. Nährung 38, 178-191.

Maynard LA \& Loosly JK (1979) Animal Nutrition, 6th ed. New York, NY: McGraw-Hill Book Co.

Melamed P, Eliahu N, Levavi-Sivan B, Ofir M, Farchi-Pisanty O, Rentier-Delrue F, Smal J, Yaron Z \& Naor Z (1995) Hypothalamic and thyroidal regulation of growth hormone in tilapia. General and Comparative Endocrinology 97, 13-30.

Mol KA, Van der Geyten S, Burel C, Kühn ER, Boujard T \& Darras VM (1998) Comparative study of iodothyronine outer ring and inner ring deiodinase activities in five teleostean fishes. Fish Physiology and Biochemistry 18, 253-266.

National Research Council (1993) Nutrient Requirements of Fish. Washington, D.C.: National Academic Press.

Nugon-Baudon L \& Rabot S (1994) Glucosinolates and glucosinolate derivatives: implications for protection against chemical carcinogenesis. Nutrition Research Reviews 7, 205-231.

Rabot S, Nugon-Baudon L \& Szylit O (1993) Alterations of the hepatic xenobiotic-metabolizing enzymes by a glucosinolaterich diet in germ-free rats: influence of a pre-induction with phenobarbital. British Journal of Nutrition 70, 347-354.

Roland N, Rabot S \& Nugon-Baudon L (1996) Modulation of the biological effects of glucosinolates by inulin and oat fibre in gnotobiotic rats inoculated with a human whole faecal flora. Food and Chemical Toxicology 34, 671-677.

Spinelli J, Houle CR \& Wekell JC (1983) The effect of phytates on the growth of rainbow trout (Salmo gairdneri) fed purified diets containing varying quantities of calcium and magnesium. Aquaculture 30, 71-83.

Teskeredzic Z, Higgs DA, Dosanjh BS, McBride JR, Hardy RW, Beames RM, Jones JD, Simell M, Vaara T \& Bridges RB (1995) Assessment of undephytinized and dephytinized rapeseed protein concentrate as sources of dietary protein concentrate as sources of dietary protein for juvenile rainbow trout (Oncorhynchus mykiss). Aquaculture 131, 261-277.

Thivend P, Mercier C \& Guilbot A (1972) Determination of starch with glucoamylase. In Methods in Carbohydrate Chemistry, vol. IV, pp. 100-105 [RL Whistler and JN Bemiller, editors]. New York, London: Academic Press.

VanEtten CH \& Tookey HL (1983) Glucosinolates. In Handbook of Naturally Occuring Food Toxicants, p. 15 [M Rechcigl, editor]. Boca Raton, FL: CRC Press.

Vermorel M \& Baudet JJ (1987) Valorization of rapeseed meal. 2. Nutritive value of high or low-glucosinolate varieties and effect of dehulling. Reproduction, Nutrition, Développment 27, 45-55.

Vemorel M, Heaney RK \& Fenwick GR (1986) Nutritive value of rapeseed meal: effects of individual glucosinolates. Journal of Sciences of Food and Agriculture 37, 1197-1202.

Webster CD, Tiu LG, Tidwell JH \& Grizzle JM (1997) Growth and body composition of channel catfish (Ictalurus punctatus) fed diets containing various percentages of canola meal. Aquaculture 150, 103-112. 
Williamson G, Wang H \& Griffiths S (1996) Glucosinolates as bioactive components of Brassica vegetables: induction of cytochrome P450 1A1 in Hep G2 cells as assessed using transient transfection. Biochemical Society Transactions 24, 383 S.

Woo NYS, Chung ASB \& Ng TB (1991) Influence of oral administration of 3,5,3'-triiodo-L-thyronine on growth, digestion, food conversion and metabolism in the underyearling red sea bream, Chrysophrys major (Temminck \& Schlegel). Journal of Fish Biology 39, 459-468.

Yurkowski M, Bailey JK, Evans RE, Tabachek J-AL \& Burton Ayles G (1978) Acceptability of rapeseed proteins in diets of rainbow trout (Salmo gairdneri). Journal of the Fisheries Research Board of Canada 35, 951-962. 